\title{
インピーダンス変化を利用した排尿検知システム
}

\author{
大橋 一男*, 原 克俊, 北折 典之 \\ 花王株式会社ヘルスケア第 2 研究所（テ131-8501 墨田区文花 2-1-3）
}

\section{Development of Urinary Detection System by Taking Advantage of the Change Rate in Impedance}

\begin{abstract}
Kazuo OHASHI, ${ }^{*}$ Katsutoshi HARA, and Noriyuki KITAORI
Health Care Products Research Laboratories No.2, Kao Corporation (2-1-3 Bunka, Sumida-ku, Tokyo 131-8501, Japan)

Received December 7, 2001 ; Accepted February 18, 2002

We developed a monitoring system for determining the excretion and urinary volume based on the changes in impedance of disposable diaper. This method has an advantage over other methods in that urinary volume can be measured without direct contact. The urinary volume was calculated based on the change rate of impedance. We found that the correlation coefficient between the urinary volume and the change rate of impedance was 0.96 , suggesting the possibility of quantitative analysis. In addition, it was found that the slope between the urinary volume and the change rate of impedance was shifted by the movement of a person. The slope corrections were carried out using two acceleration sensors. Furthermore, we evaluated the monitoring system in a nursing home. The sensor output chart agreed with the motions obtained in a daily schedule and showed the urinary incontinence time.
\end{abstract}

Key Words : Monitoring System, Impedance, Sensor, Excretion, Urinary volume

\section{1 緒 言}

近年，先進諸国では国民の高年齢化が問題視され，それに 伴う諸課題が取りざたされている。㶱国内でも，2025 年 には，国民の 4 人に一人は 65 才以上の高年齢者となり，そ のために必要な社会整備の早急な充実が議論されている ${ }^{1)}$. 特に日常の介護に扔いては，排泄と食事が介護者ならびに被 介護者の大きな負担であり，今後の充実した老後生活と社会 福祉達成の妨げとなっている。加えて，排泄介護に関しては， 被介護者の人権もあり誰でも行うというわけにはいかない.

一方，衛生面および利便性などの点から，介護施設をはじ め在宅でも紙㧍むつが使われるようになってきたままた，市 販されている紙おむつは年々改良が加えられ，実際の使用範 囲では， 2 から 3 回程度の排尿を蓄えることが可能である2). しかしながら，一般的な使用では，紙おむつ許容量の半分程 度以下の尿量で，おむつを交換している場合が多く，おむつ の廃立量の増大を招き環境の負担が大きくなる．これに反し， 排尿を大量に含んだ紙抢むつをそのまま長時間放置すれば， 肌荒れを招き，特に寝たきりの人には床ずれを誘発する原因 となり問題である. 加えて, 介護者が頻繁に排泄を確認する ことは, 被介護者個人の尊厳扝よび安眠を阻害する恐れがあ る。このように排洲介護は, 大変煩雑であり負担も大きく難 しい課題である.

これらの社会的要求から，排泄のほとんどを占める排尿を 検知するセンサやシステムの研究が盛んに行われ，電気化学 デバイスの応用展開が検討されている．例えば，導電率の変 化 $^{3-5)}$, 温度変化 ${ }^{6-10)}$, ガスセンサ ${ }^{11)}$, 静電容量変化 ${ }^{12)}$,
静電容量センサと歪みセンサ ${ }^{13)}$, 赤外線の反射 ${ }^{14)}$, 湿気セン サ15)，およびインピーダンスセンサを使用 ${ }^{16-19)}$ したものなど が多数提案, 研究㧍よび報告されている.しかしながら, 実 際に商品化されている原理のほとんどが排尿に伴う導電率の 変化を捉えて検知するものである．ところが導電率センサは， 汗で電極間が導通し誤動作してしまう，センサ部が排尿で污 れる，センサ部が使い捨てで無駄があるならびに排泄尿量が 検知できないなどの欠点があり ${ }^{4)}$, 実際の使用では利用者に 十分な满足を与える物ではない。

そこで紙おむつ利用者の声をまとめ，我々は，紙おむつが 複数回の排㲾に対応しているにも拘わらず吸収限界範囲内ま で使用していないという事実に配虑し，尿量を検知（複数回 の排尿を検知）することが可能で，排泄物とセンサ部が非接 触で検知できることから誤動作する可能性の少ない，インピ ーダンスの変化を利用した排尿センサについて検討した。そ の結果, センサシートの電極配置に工夫を加え, インピーダ ンス変化を測定することにより排尿量を概ね定量出来ること を見出した．さらに，実際の使用では体位（姿勢）により， 検出值が大きく変わる問題があるが, その課題に対して加速 度センサを検知システム内に加え, 被介護者の姿勢を判断す ることで解決できることを見出した，そこで，一つの典型的 なモデルケースとして, 実際の施設で規則正しく介護されて いる被介護者を対象に, 実使用テストを行った。その結果, 実際の使用でも十分対応できる可能性があることがわかった. 本報告では, これらの開発, 改良経過について詳細に述べ ると共に, 介護施設での実使用の結果と今後の展開について 


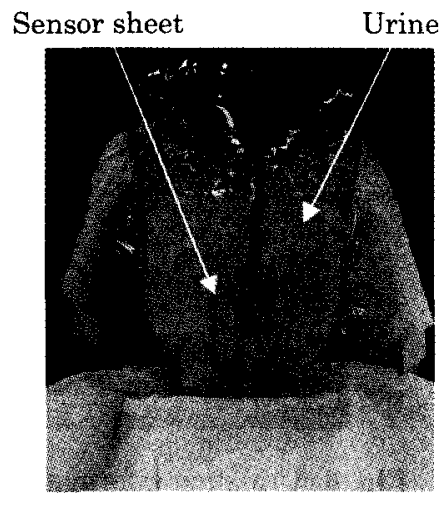

Inside

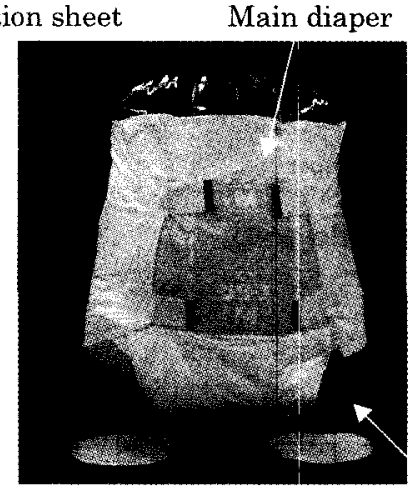

Outside

Fig. 1 Photographs of sensor sheet and diaper setup.

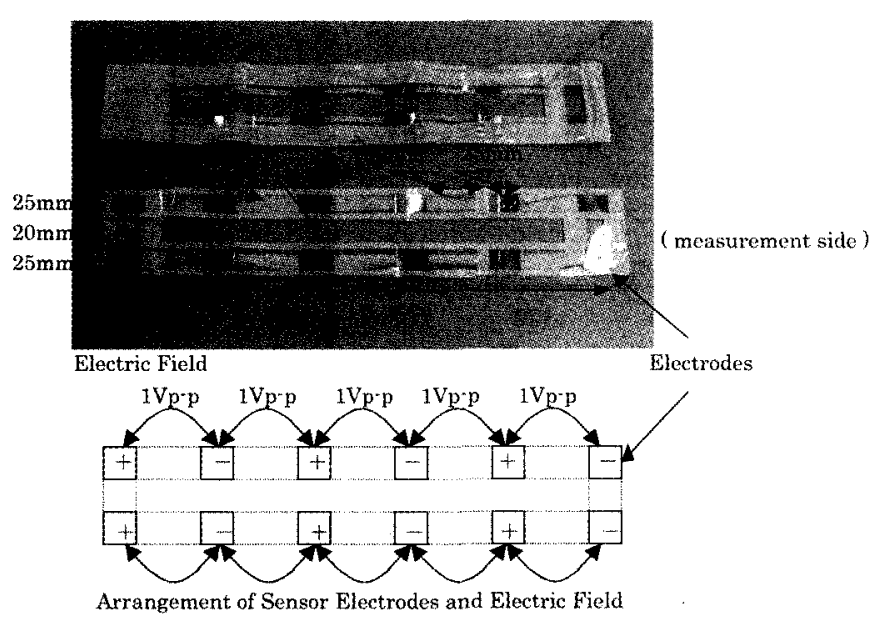

Fig. 2 Arrangement of electrodes on the sensor sheet.

記載する。

\section{2 実験方法}

2. 1 センサシートの電極配置ならびにインピーダンス測定 方法

実際に老人介護で使用される紙おむつの形態は，排尿した 際の漏れ防止抢よびコスト面から，通常の介護用おむつの中 に，さらに尿取りパッドを重权て使用する場合が多い，そこ で，本実験では，紙扔むつの内部に尿取りパッドを入れた場 合について検討を行った. Fig. 1 に紙打むつ並びにセンサ電 極を貼り付けた尿取りパッドの写真を示す，紙㧍むつは，リ リーフテープ止めタイプ M サイズ (花王(株)製)，尿取りパ ッドは尿取りパッドスーパー（花王(株)製）を用いた。
Fig. 2 に実験に使用したセンサシートの構成図を示す。電 極には，市販の厚み $0.1 \mathrm{~mm}$ の銅䈃テープを用い, 透明フィ ルム上に貼り付け作製した。センサシートは，排尿の姿勢， 男女差拉よび個人差を考慮し，排尿を確実に検出するために， 尿取りパッド全面を覆う大きさとし，電極をマトリックス状 に複数枚配置し，全ての電極対を並列に接続した．また，装 着した際に違和感が無いようシート中央部の透明フィルムを 取り除いた形状とした。

Fig. 3 に今回使用した尿取りパッドの断面因ならびに測定 系の概略図を示す，尿取りパッドは，主にさらさらシート， 吸水層，防水シートから構成される．ささらさらートは，尿 の逆戻りを防止することで，常時おしりに快適性を提供する。 吸水層は，高分子吸収体を含有することで尿を保持し，防水 シートは外部への尿漏孔を防止するためのものである.

センサシートは直接排尿に接することがない防水シート側 に取り付けた。インピーダンスの測定には，インピーダンス アナライザ（横河ヒューレットパッカード社製 4192ALF） を用いた、インピーダンスの測定は，隣合う電極同士が干渉 し，測定誤差の誘発を防止するために，Fig. 2 に記載した電 極対の全てを並列に接続し, 印加電圧 $1 \mathrm{~V}_{\mathrm{p}-\mathrm{p}}$ （最大電圧 0.5 $\mathrm{V}$ の正弦波)，周波数 $500 \mathrm{kHz}$ で行った.

\section{2 排尿量検知の検討（模型を使用した模擬テスト）}

Fig. 1 に示したビニール製の人体模型を使用し，排尿とし て擬似的に水道水（以下水と省略する）をシリコンチューブ から尿取りパッド内部に注入し排尿量検知の可能性を検討し た。注入量は，1回あたり $50 \mathrm{ml}$ で，5分間隔で計 8 回，400 $\mathrm{ml}$ まで注水し，注入毎にセンサシート上の電極間インピー ダンスを測定した。インピーダンスの測定は，2.1で前述し た测定方法ならびにセンサシートを用いて行った。

The cross section of urine absorption sheet

Dry sheet

Water absorbent layer

Waterproof sheet

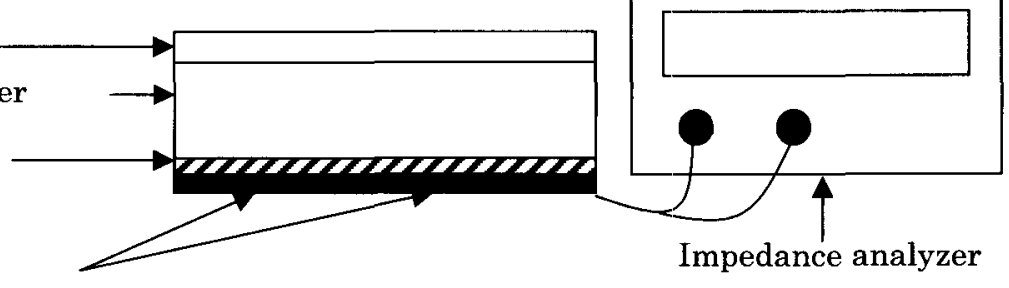

Sensor sheet

Fig. 3 Impedance measurement system. 


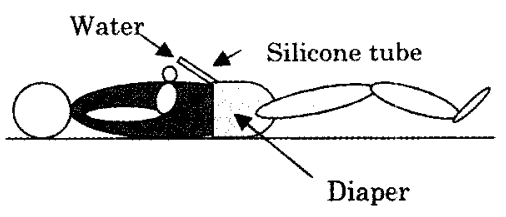

Fig. 4 Scheme of model test.

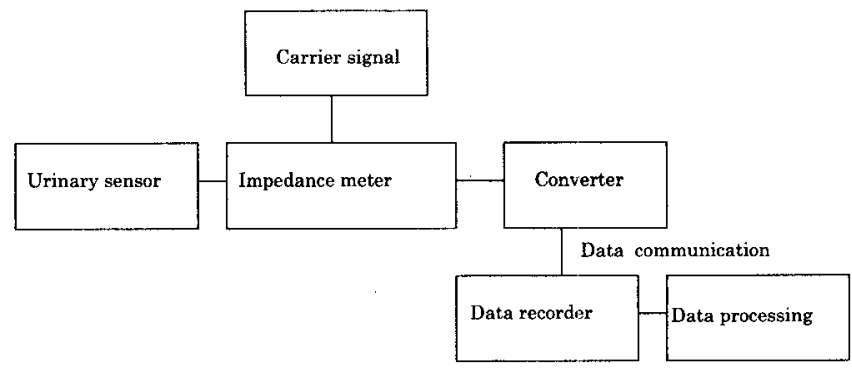

Fig. 5 Block diagram for determining urination information.

尚，水道水によっても多少のばらつきはあるものの，尿と 水道水のインピーダンスを測定比較した結果は, 注入水量 $100 \mathrm{ml}$ で 6 7 k $\Omega$ 程度の範囲でほほ同じであった。そこで, 実験では，センサーの基本特性を得ることを主眼としたため， 簡便性を考慮して水道水を使用した。本実験の範囲では，水 道水質による導電率のばらつきよりも，静電容量の影響が大 きいため，インピーダンスの測定結果はほほ同じ值になった と考えられる。

\section{3 排尿時間ならび尿量検知の疑似テスト}

人体における排尿時間と尿量検知の検討を行うために, Fig. 4 に示すようにボランティア 1 名が尿取りパッドおよび 紙おむつを実際に装着し，シリコンチューブから水を尿取り パッド内に注入した，注入量は，2.2 と同様，1回あたり 50 $\mathrm{ml}, 5$ 分間隔で計 6 回, $300 \mathrm{ml}$ まで注水し, 注入毎の電極 間インピーダンスを測定した。また，人体の姿勢による影響 を確認する目的で，(1)仰向けに寝る，(2)座る，(3)立つの3つ の基本姿勢でテストを行った. $2.1 ， 2.2$ の実験では, イン ピーダンスアナライザでセンサシート上の電極間インピーダ ンスを測定していたが，装置が大きく持ち運びに不便である 等の理由から，実用的ではなかった，そこで，今回の測定系 はより実用的な検討を行う意味で，インピーダンス変化を電 圧変化に変換して測定した．測定装置のブロック図を Fig. 5 に示す。

\section{4 施設被介謨者による使用テスト}

栃木県内にある特別保健施設において，本人ならびに家族 の了承のもと, 実使用テストを行った. 被介護者は, 80 歳 代の女性である。紙打むつは，2.1〜2.3で使用した紙おむ つおよび尿取りパッドと同一のものを使用した，尿取りパッ ドの外側にセンサシートを貼り付け, 排泄の状況を 2.3 で使 用した測定系を用いて実使用テストを行った。 また，同時に 姿勢情報を得るために, 2 つの加速度センサも設けた. Fig. 6 に今回使用した測定システムを示す。センサによる排泄およ び姿勢情報は，経時的にパソコンに取り込むことが可能であ り, 実用テスト終了後, 解析を行った。 また, 姿勢に関して は, 被介護者の動きを実際に観察するとともに加速度センサ 出力との比較検討も行った.

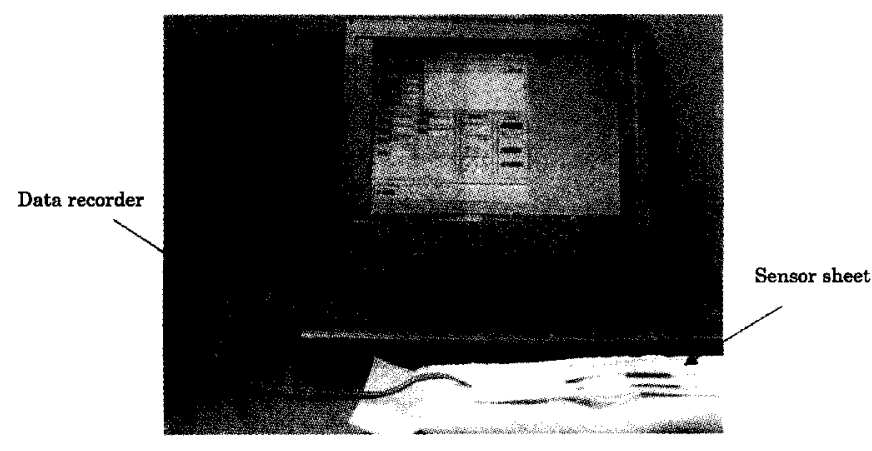

Fig. 6 Urination information monitoring system.

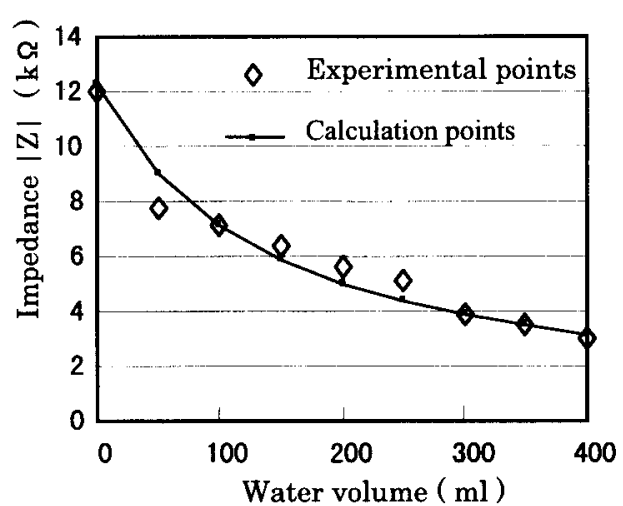

Fig. 7 Water volume dependence of impedance in diaper.

\section{3 結果および考察}

\section{1 インピーダンスの変化による排尿量検知の検討}

尿取りパッドの吸収できる排尿量は，実際の使用範囲では 2 から 3 回程度の排尿を蓄えることが可能である.インピー ダンスの変化量から排尿量の検知が出来れば, 尿取りパッド の有効利用が可能となると共に, 複数回の排尿検知の可能性 が示唆できる.そこで, 2.2 で述べた実験方法で注入水量と センサシート上の電極間インピーダンス（絶対值）を測定し た. その結果を Fig. 7 に示す. Fig. 7 の横軸は注入した水の 量, 縦軸はセンサシート上の電極間インピーダンスである. Fig. 7 から，尿取りパッド内に含まれる水の量が増加するに 伴いセンサシート上の電極間インピーダンスが減少すること がわかる. Fig. 7のインピーダンス変化を詳しく見るために, インピーダンスを抵抗成分と静電容量成分に分割した。 その 結果を Fig. 8 に示す. Fig. 8 の横軸は注入した水の量, 絴軸 はセンサシート上の電極間インピーダンスの抵抗成分と静電 容量成分である.

本測定系の等価回路は，尿取りパッドの防水シートの静電 容量成分 $\left(\mathrm{C}_{0}\right)$, 扔よび, 使用した水が水道水であり電気を 流すことから（排尿も同じ）, 水道水を含んだ高分子吸収剂 (電解質) の抵抗成分 $\left(\mathrm{R}_{\mathrm{W}}\right)$ と静電容量成分 $\left(\mathrm{C}_{\mathrm{W}}\right)$ で構成さ れる, Fig.9（a）と表される. 本等価回路での合成インピー ダンス (Z) は,

$$
Z=R_{W} /\left(1+j \omega C_{W} R_{W}\right)+2 / j \omega C_{0}
$$

と表される，ところが，インピーダンスアナライザーの測定 值は, Fig.9（b）に示した抵抗成分 (R) と静電容量成分 (C) の並列回路として得られる. そこで, 式(1)を測定値に 


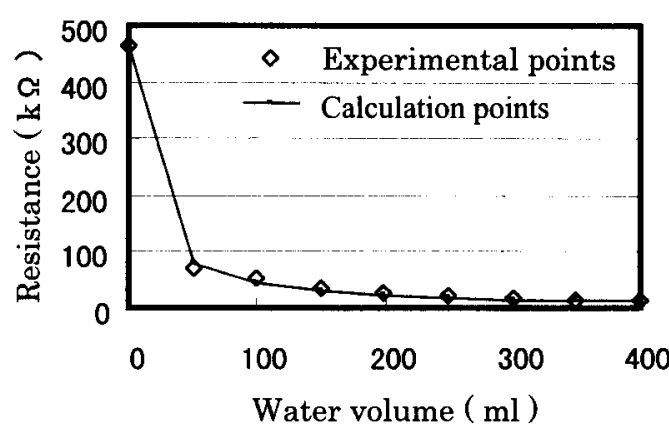

(a) Resistance component

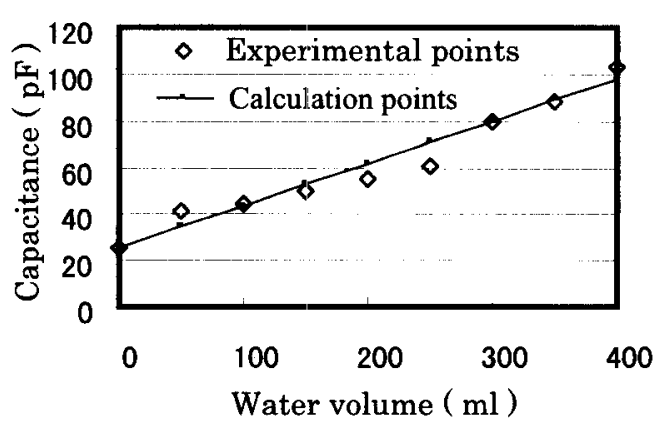

( b ) Capacitance component

Fig. 8 Water volume dependence of capacitance and resistance of diaper.
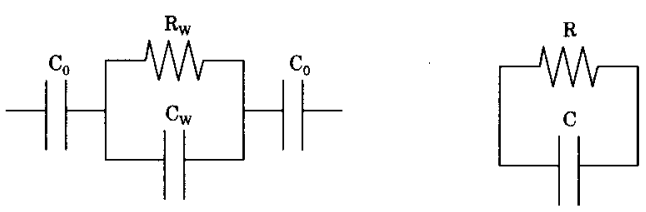

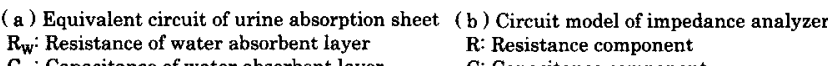
$\mathrm{C}_{\mathrm{W}}$ : Capacitance of water absorbent laye $\mathrm{C}_{0}$ : Capacitance of waterproof sheet

Fig. 9 Equivalent circuit model.

対応するように分離すると，

$\mathrm{R}=\left\{2^{2}+\omega^{2} \mathrm{RW}^{2}\left(\mathrm{C}_{0}+2 \mathrm{C}_{\mathrm{W}}\right)^{2}\right\} /\left(\omega^{2} \mathrm{Rw}_{0} \mathrm{C}_{0}\right)$

$\mathrm{C}=\mathrm{C}_{0}\left\{2+\mathrm{C}_{\mathrm{W}} \omega^{2} \mathrm{Rw}^{2}\left(\mathrm{C}_{0}+2 \mathrm{C}_{\mathrm{W}}\right)\right\} /\left\{2^{2}+\omega^{2} \mathrm{Rw}^{2}\left(\mathrm{C}_{0}+2 \mathrm{C}_{\mathrm{W}}\right)^{2}\right\}$

となる．本測定系において，防水シートの $\mathrm{C}_{0}$ は，その厚み が数十 $\mu \mathrm{m}$ であることから， $\mathrm{nF}$ オーダと考えられ， $\mathrm{C}_{\mathrm{W}}$ は 数十 $\mathrm{pF}$ であり無視でき，以下のように近似できる。

$$
\mathrm{C}_{0}+2 \mathrm{C}_{\mathrm{W}} \doteqdot \mathrm{C}_{0}
$$

さらに，測定周波数が $500 \mathrm{kHz}$ において， $\mathrm{R}_{w}$ が数十 $\mathrm{k} \Omega$ で あり，式(2)，(3)の $\mathrm{C}_{\mathrm{w}} \omega^{2} \mathrm{Rw}^{2}\left(\mathrm{C}_{0}+2 \mathrm{C}_{\mathrm{w}}\right)$ と $\omega^{2} \mathrm{Rw}^{2}\left(\mathrm{C}_{0}+2 \mathrm{C}_{\mathrm{W}}\right)^{2}$ は数百以上となり, 2 および $2^{2}$ は無視できる. 加えて, 式 (4) を代入し，整理すると，

$$
\begin{aligned}
& 2+\mathrm{C}_{\mathrm{W}} \omega^{2} \mathrm{Rw}^{2}\left(\mathrm{C}_{0}+2 \mathrm{C}_{\mathrm{W}}\right) \doteqdot \mathrm{C}_{\mathrm{W}} \omega^{2} \mathrm{Rw}^{2} \mathrm{C}_{0} \\
& 2^{2}+\omega^{2} \mathrm{R}_{\mathrm{W}}^{2}\left(\mathrm{C}_{0}+2 \mathrm{C}_{\mathrm{W}}\right)^{2} \doteqdot \omega^{2} \mathrm{R}_{\mathrm{W}}{ }^{2} \mathrm{C}_{0}^{2}
\end{aligned}
$$

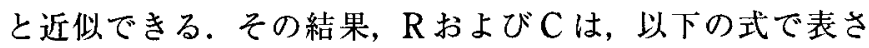
れる。

$$
\begin{aligned}
& \mathrm{R} \doteqdot \mathrm{R}_{\mathrm{w}} \\
& \mathrm{C} \fallingdotseq \mathrm{C}_{\mathrm{w}}
\end{aligned}
$$

この結果より, Fig. 8 の抵抗成分および静電容量成分は，水 が尿取りパッドに染み込んでできた電解質の抵抗成分および 静電容量成分であることがわかる.

次に，おのおのの成分について考える.Fig.8（a）より抵 抗成分は注入水量の増加と共に減少する。この減少は，尿取 りパッドに水を注入することにより，水の影響で水が注入さ
れた近傍電極間で電流が流れやすくなることに起因する。す なわち, 電極問の高分子吸収剤の抵抗率が水を注入すること で低下すると考えられる。このことから，抵抗は注入水量の 逆数に比例すると考えた. 加えて, 実験結果と注入水量が無 い場合 $(\mathrm{W}=0)$ での抵抗成分の実測值は $465 \mathrm{k} \Omega$ であるこ とを考虑して, 近似式(9)を求めた。

$$
\begin{aligned}
& \mathrm{R}=465 /(0.09 \times \mathrm{W}+1) \quad(\mathrm{k} \Omega) \\
& (\mathrm{W}: \text { 注入水量 } \mathrm{ml})
\end{aligned}
$$

Fig. 8（a）計算值に示すように，近似式 (9)は測定結果とよ く一致した。

一方, Fig. 8（b）より静電容量成分は注入水量の増加と 共に大きくなっていることがわかる．この増加は，尿取りパ ッド中に, 比誘電率が高い水（比誘電率 81）が吸収される ことにより，電極間の物体の誘電率が上昇することに起因す る.このことから, 静電容量は注入水量の一次関数と表すこ とができる．さらに，実験結果と注入水量が無い場合での静 電容量の実測值が26 (pF) であることを考慮して近似式 (10)を求めた.

$$
\begin{aligned}
& \mathrm{C}=0.18 \times \mathrm{W}+26 \quad(\mathrm{pF}) \\
& (\mathrm{W}: \text { 注入水量 } \mathrm{ml})
\end{aligned}
$$

Fig. 8（b）計算値に示すように，近似式(10)は測定結果と よく一致した.

以上, 求めた結果を組み合わせて, センサーシート上の電 極間インピーダンス $(|Z|)$ を式(11)を用いて算出し,

$$
|Z|=1 / \sqrt{ }\left\{(1 / \mathrm{R})^{2}+(\omega \mathrm{C})^{2}\right\}
$$

実験結果と比較した，その結果，Fig. 7 の計算值に示すよう に測定結果と良く一致した。

以上のことから，本センサで排尿の検知および尿量の計測 が可能である，また，尿量の変化を検知することで，今後， 排尿回数の検知も可能であることがわかった.

\section{2 排尿検知の疑似テスト}

排泄センサを使用する対象となる人の多くは高齢者であり， 排泄の介助が必要な方である。この様な人の場合, 歩き回る ことは少なく, 立つ, 寝る (仰向け, 横向き), 座る等の動 作がほとんどである，そこで，本センサシートを使用し三つ の姿勢 (立つ, 寝る, 座る) に伴う注入水量とセンサシート 


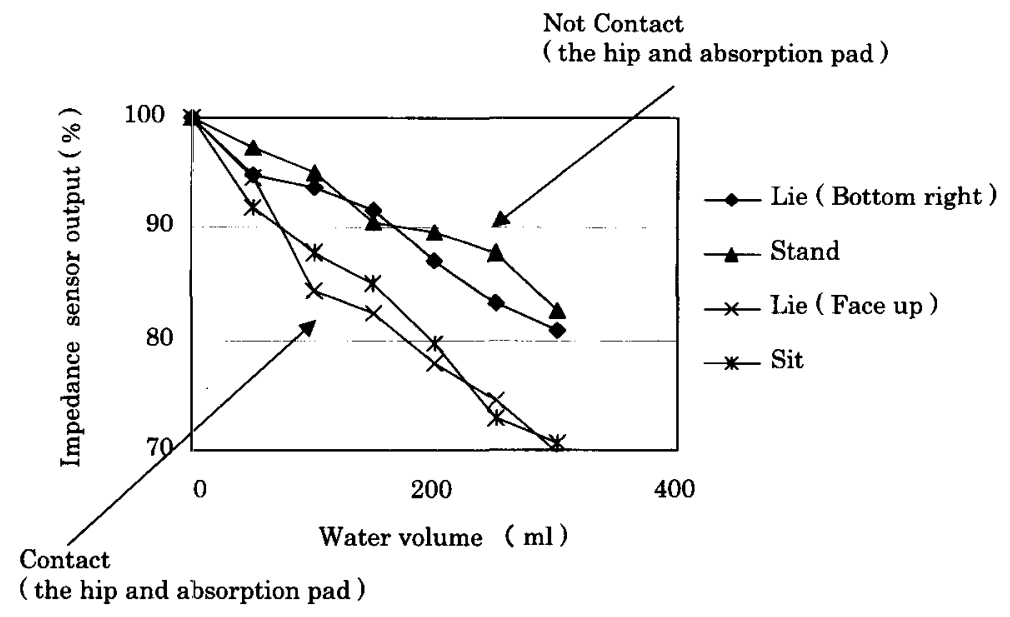

Fig. 10 Water volume dependence of impedance sensor output. $($ Impedance sensor output $(\%)=($ measurement level/base level $) \times 100)$

Table 1 Typical daily schedule in a nursing home.

\begin{tabular}{c|c|c} 
Time & Schedule & Posture \\
\hline $6: 00$ & Rising & Lying \\
$7: 00$ & Diaper exchange & \\
$8: 00$ & Breakfast & Sitting \\
$9: 00$ & Diaper exchange & \\
$10: 00$ & Take a tea & \\
$11: 00$ & & \\
$12: 00$ & Lunch & \\
$13: 00$ & Diaper exchange & Lying \\
$14: 00$ & Recreation & Sitting \\
$15: 00$ & Afternoon tea & $\downarrow$ \\
$16: 00$ & Diaper exchange & Lying \\
$17: 00$ & Supper & Sitting
\end{tabular}

上の電極間インピーダンスの変化量を測定した。 センサシー ト上の電極間インピーダンスの測定は, 実際の使用に合わせ インピーダンスを自作の回路で電圧に変換して測定した．以 降では，この回路から得られた電圧をインピーダンスセンサ 出力と記す. 测定結果を Fig. 10 に示す. Fig.10の横軸は注 入水量, 縦軸はインピーダンスセンサ出力の変化率である. インピーダンス出力の変化率とは, 注入水量が 0 の場合の出 力を基準 $(100 \%)$ として，そこからの変化量を百分率で示 したものである. Fig. 10の解析から, 注入水量とインピー ダンスセンサ出力の変化率との関係は, 立つ, 横向きに寝る 場合と，座る，仰向けに寝る場合の 2 通りのグループに分け られることがわかった. インピーダンスセンサ出力の変化が

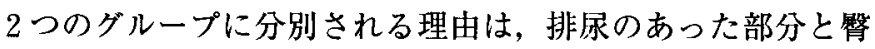
部との接触状態の影響と考えられる．具体的には，立ってい たり横向きに寝ている場合には, 尿取りパッドの水含浸部と 臂部とに隙間が存在し, 接触がないため, インピーダンスセ ンサ出力は尿取りパッドに注入された水の影響のみを捕らえ ていると考えられる。一方, 座っている場合と仰向けで寝て いる場合には，臂部と尿取りパッドの水含浸部は密着し，人 体のインピーダンスの影響で変化率が大きくなるものと考え られる。また，人体の影響があっても注入水量が多くなるに 従いインピーダンスセンサ出力が隇少していくのは, 尿取り パッド全面を覆うように電極をマトリックス状に配置してい
るため, 水含浸部分の領域が広がり，インピーダンスの変化 が複数の電極对に及ぶためと考えられる.

以上のように，2つのグループでインピーダンスセンサ出 力の変化量は各々異なるが, 水量に対し一次的に変化し, 立 つ，横向きに寝るの場合，

インピーダンスセンサ出力変化量 $(\%)$
$=-0.058 \times$ 注入水量 $(\mathrm{ml})+99.8$

仰向けに寝る，座るの場合，

インピーダンスセンサ出力変化量 $(\%)$
$=-0.097 \times$ 注入水量 $(\mathrm{ml})+98.2$

で表される．また，各々の直線近似での相関係数は，0.96で あった．以上の結果より，注入水量とインピーダンスセンサ 出力の変化率は良い相関関係にあることがわかった．また， 得られた関係式よりインピーダンスセンサー出力変化率から 注入水量を定量出来ることが示された.

\section{3 施設被介讙者による使用テスト}

Table 1 は, 特別老人保健施設での入所者の典型的な生活 パターンである．要介護度が小さい方ほど動きのパターンが 複雑となる ${ }^{20)}$ 。また, 寝たきりの方でも，床ずれ防止のため に定期的に体位を変えたり，レクリエーション，娱楽および 入浴をするために車椅子による移動が行われている.

3.2 の結果から姿勢がわかれば尿量は定量出来ることが示 された.したがって，実際の施設や在宅で実用化するために は，基本姿勢を検知しなければならない。人体の行動を测定 する方法としては，上肢での試みではあるが，加速度センサ による検討が報告されている21)。そこで, 我々は加速度セン サ（アナログ・デバイス株式会社製 ADXL202：x-y, 2 軸 の傾き測定が可能）を使用し，人体に対して左右を $\mathrm{x}$ 軸とし， 頭から足にかけてを $\mathrm{y}$ 軸として, 被介護者の姿勢を検知する ことにした．Fig. 11 に姿勢と加速度センサ出力の関係概略 図を示した. Fig.11 から分かるように, $\mathrm{x}$ 軸の加速度セン サ出力で左右情報がわかる．また，y 軸の加速度センサ出力 で立つあるいは座っているのか，寝ているのかがわかる，両 方の情報を組み合わせることにより，右を下にして寝ている 


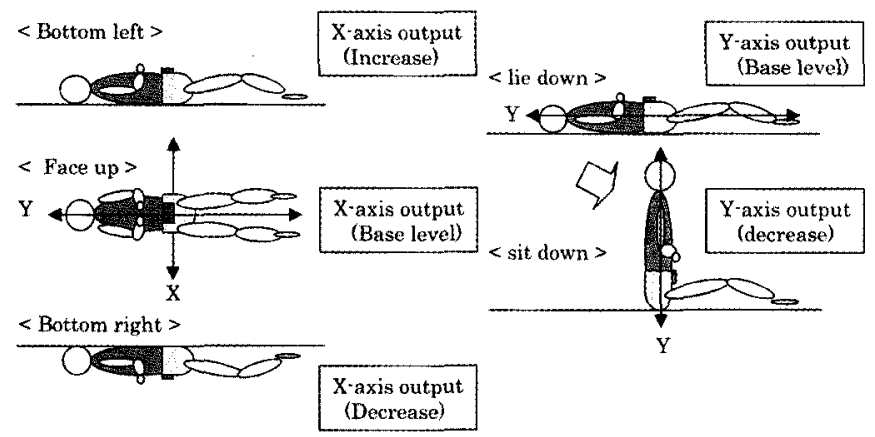

Fig. 11 Definition of two dimensions on personal motion. (X-axis: left or right , Y-axis: lie or sit down)

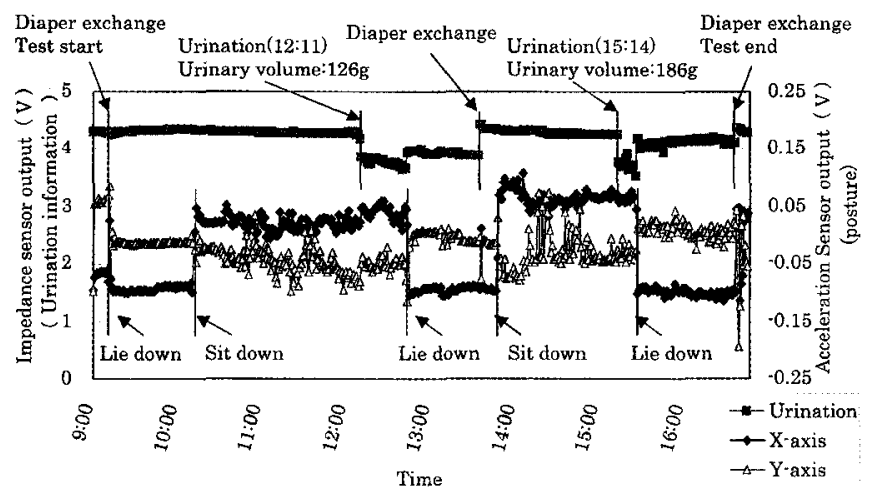

Fig. 12 Output chart of urination incontinence and posture sensor.

などの情報を得ることができるのである。

次いで，実使用に対応できる姿勢検知センサを加えた排尿 検知システムを作製した. Fig. 6 で示した本システムは，デ 一夕処理用パーソナルコンピュー夕, センサシートとデー夕 記憶部から構成され, 被介護者の排泄データをデー夕記憶部 に取り込むことができる，取り込んだデータは，パーソナル

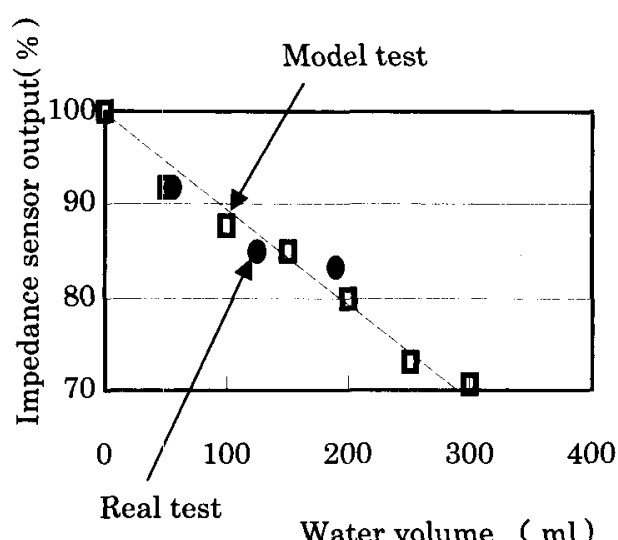

Fig. 13 Plots of water $(\square)$ and urinary ( $(\bigcirc)$ volumes vs. impedance sensor output. (Impedance sensor output $(\%)=$ (measurement level/base level) $\times 100$ )

コンピュータに取り込むことで排尿時間や排尿量の解析がで きる。このシステムを用いて, 特別老人保健施設で被介護者 に使用して测定を行った。その結果を Fig. 12 にまとめて示 す. Fig. 12 は縦軸がインピーダンスセンサと加速度センサ の出力, 横軸が時刻である. Fig. 12 に示すように, 加速度 センサの出力は, 姿勢で変化し, インピーダンスセンサ出力 も排尿で変化している. Fig. 12 を解析することにより, Table 2 に示すように被介護者の姿勢や排尿の状況が明らかと なる.Fig.12中の尿量は, 天秤で実測した值である。この 值は座った姿勢での尿量である.そこで, Fig. 10 で示した 座った姿勢でのインピーダンスセンサ出力変化率と注入水量 のダラフにプロットし比較した。そ結果を Fig. 13 に示す. Fig. 13 は，座った姿勢での疑似テストで得られたデー夕 （口）と被介護者での実使用時デー夕（○）との比較である. Fig. 13 より，実際の排尿データが 3.2 で得られたデー夕の 直線近似直線上にプロットされることから，実際の使用でも

Table 2 Urination and posture information chart.

\begin{tabular}{|c|c|c|c|c|}
\hline Time & $\begin{array}{c}\text { Impedance } \\
\text { sensor output }\end{array}$ & $\begin{array}{l}\text { Urination } \\
\text { Information }\end{array}$ & $\begin{array}{c}\text { Acceleration } \\
\text { sensor output }\end{array}$ & Posture \\
\hline $\begin{array}{l}9: 00 \\
\text { Start }\end{array}$ & Base level & $\begin{array}{l}\text { Diaper } \\
\text { exchange }\end{array}$ & $\begin{array}{l}\mathrm{X} \text { axis : Decrease } \\
\mathrm{Y} \text { axis : Base level }\end{array}$ & $\begin{array}{c}\text { Lie down } \\
\text { (Bottom right) }\end{array}$ \\
\hline $10: 13$ & & & $\begin{array}{l}\mathrm{X} \text { axis : Base level } \\
\mathrm{Y} \text { axis : Decrease }\end{array}$ & Sit down \\
\hline $12: 11$ & $\begin{array}{l}\text { Change } \\
\text { (Decrease) }\end{array}$ & Urination & & \\
\hline $12: 45$ & $\begin{array}{c}\text { Change } \\
\text { (Increase) }\end{array}$ & & $\begin{array}{l}\mathrm{X} \text { axis : Decrease } \\
\mathrm{Y} \text { axis : Base level }\end{array}$ & $\begin{array}{c}\text { Lie down } \\
\text { (Bottom right) }\end{array}$ \\
\hline $13: 36$ & Base level & $\begin{array}{l}\text { Diaper } \\
\text { exchange }\end{array}$ & & \\
\hline $13: 49$ & & & $\begin{array}{l}\mathrm{X} \text { axis : Base level } \\
\mathrm{Y} \text { axis : Decrease }\end{array}$ & Sit down \\
\hline $15: 14$ & $\begin{array}{c}\text { Change } \\
\text { (Decrease) }\end{array}$ & Urination & & \\
\hline $15: 27$ & $\begin{array}{c}\text { Change } \\
\text { (Increase) }\end{array}$ & & $\begin{array}{l}\mathrm{X} \text { axis : Decrease } \\
\mathrm{Y} \text { axis : Base level }\end{array}$ & $\begin{array}{c}\text { Lie down } \\
\text { (Bottom right) }\end{array}$ \\
\hline $\begin{array}{c}16: 36 \\
\text { End }\end{array}$ & Base level & $\begin{array}{l}\text { Diaper } \\
\text { exchange }\end{array}$ & & \\
\hline
\end{tabular}


インピーダンスセンサ出力の変化から尿量を定量できること が示唆された。

今後さらに，本報告のシステムをパソコンと接続し時間管 理することにより，被介護者の姿勢，排尿時間，排尿量，お むつ交換の時間が把握できる。 また，その結果を利用するこ とで，個人の尊厳を守りつつ，排泄のケアが迅速にかつ利便 的にできることが可能と思える．さらに，排尿後の放置で起 こる肌荒れの防止や，効果的なオムツ交換，不要なオムツの チェックを無くす事で夜間の安眠を妨げない等の効果がある。 また，水分搷取量をはじめとする被介護者の情報と排尿の状 況を排尿チャートに記録することで，排尿の状況や排泄パ夕 ーンを把握でき, 被介護者自身での排尿の習慣づけや, 尿意 回復のトレーニングにも応用が期待される22-25).

\section{4 結 論}

今後, 高齢者の人口は益々増加する. 老人介護では, 排泄 のケアが大きな課題であり，充実した介護のためには排泄セ ンサの社会的要求は高い。 そこで, 我々は，排泄物に非接触 で, 排尿時刻と排尿量をインピーダンスの変化で求めること を検討した. その結果, 以下の 3 つ事を明らかにした。

1.インピーダンスセンサは, 尿取りパッド外側から（非接 触で)，排尿の検知と排尿量の変化を测定できる.

2.ただし，姿勢によってインピーダンスの変化率が異なる。

3. 加速度センサを用い $\mathrm{x}-\mathrm{y} 2$ 軸の変化量から, 人体の左右, 上下の動きを把握することで，人体の姿勢を検知でき，実 使用に招いてもインピーダンスセンサにより排尿測定が可 能になった。

今後さらにデー夕を積み重ねて行くことで, 本報告のシス テムを活用することにより，排尿後の放置で起こる肌荒れの 防止や, 効果的なオムッ交換, 不要なオムッのチェックを無 くすことが可能と思える.さらに，水分摂取量その他の被介 護者の情報と排尿の状況を検討することで，尿意回復のトレ ーニングにも応用が期待される。

\section{文献}

1）藤元登四郎, 橋本武雄, 榊 広光, 東 祐二, Clinical En- gineering, 8, 670 (1997).

2）塚崎恵子，牧本清子，金大医紀要，19，131（1995）。

3）庄司濱子, 成田弘子, 木野正彦, 静岡県衛生環境センター報 告, 35, 119 (1992).

4）長谷川雄一，センサ技術，12，72（1992）.

5）上田照子, 橋本美香子, 中園直水, 日本公衛誌, 42, 398 (1995).

6）松下孝之, 田村利世, 藤元登四郎, 中野寿彦, 医用電子と生 体工学, 31, 261 (1993).

7) 松下孝之, 中島一樹, 下沖 晋, 中野寿彦, 藤元登四郎, 田 村利世, 三池秀俊, 電子情報通信学会 信学技報, MBE 93，39 (1994).

8）長沢 正, 望月紀寿, 静岡県富士工業技術センター報 告, 6, 79 (1996).

9）吉沢尚幸, 大嶋 剛, 栃木県工業試験研究機関研究集録, 65 (1997).

10) T. Tamura, K. Nakajima, T. Matsushita, T. Fujimoto, I. Shimooki, and T. Nakano, Proc. Annu. Int. Conf. IEEE Eng. Med. Biol. Soc. , 15, 998 (1993).

11）辻 隆之, 藤元登四郎, 森反俊之, 土肥健純, Clinical Engineering, 8, 664 (1997).

12）大嶋 剛, 井澤倫久, 杤木県工業試験研究機関研究集録, 152 (1998).

13）佐藤博之, 特開 2000-185067.

14）坂口 明, 特開平 11-264795.

15）渡辺鉄哉, 福井県工業試験場年報, 103（1980）.

16) E. D. James, F. C. Flank, K. P. S. Caldwell, and M. R. Martin, British Journal of Urology, 43, 233 (1971).

17) S. L. Stanton and D. Ritchie, Am.J. Obstet. Gynecol., 128, 461 (1977).

18）中島一樹, 田村利世, 三池秀俊，下沖 晋，藤元登四郎，中 野寿彦, 医用電子と生体工学, 32, 97 (1994).

19）山田明夫, 布施政良, 青柳卓雄, 保坂栄弘, 柳沢 博, 東間 紘，医用電子と生体工学，7，13（1993）。

20）藤田英夫, シニア・シルバービジネス白書, 日本ビジネス開 発株式会社, 24（1999）

21）牧川方昭, 長寿科学総合研究所, 7, 61 (1997).

22）田中真木, Modern Physician, 19, 82 (1999).

23）大島博之, 長寿科学総合研究, 4, 244 (1993).

24）堀井貴司, 電気設備学会誌, 18, 552 (1998).

25）七田惠子, 老年精神医学雑誌，9，1099（1998）. 